\title{
Water Relations, Growth, and the Composition of 'Braeburn' Apple Fruit under Deficit Irrigation
}

\author{
T.M. Mills and M.H. Behboudian \\ Department of Plant Science, Massey University, Palmerston North, New Zealand \\ B.E. Clothier \\ Environment Group, HortResearch, Palmerston North, New Zealand
}

Additional index words. Malus domestica, fruit sugar, fruit osmotic potential, fruit water potential, osmotic adjustment

\begin{abstract}
Three-year-old 'Braeburn' apple trees (Malus domestica Borkh.) on MM106 rootstock were studied in a glasshouse to assess the effects of deficit irrigation on fruit growth, water relations, composition, and the vegetative growth of the trees. Trees were assigned to one of three treatments. The control (C) was fully watered. The first deficit treatment (D1) was deficit-irrigated from 55 days after full bloom (DAFB) until final harvest at 183 DAFB. The second deficit treatment (D2) was deficit-irrigated from 105 to 183 DAFB. Compared to C, the D1 and D2 trees developed a lower photosynthetic rate, leaf water potential $\left(\Psi_{1}\right)$, and stomatal conductance ( $\left.g_{s}\right)$ during the stress period. Trunk-circumference growth was reduced in both D1 and D2 trees, but leaf area and shoot length were reduced in D1 only. Total soluble solids increased in both D1 and D2 fruit. Fructose, sorbitol, and total soluble sugar concentrations were higher in D1 fruit than in $\mathrm{C}$ and D2. Titratable acidity and $\mathrm{K}^{+}$levels were higher in D1 fruit than $\mathrm{C}$ and D2. For D1, lowering of fruit water potential $\left(\Psi_{\mathrm{w}}\right)$ was accompanied by a decrease in osmotic potential $\left(\Psi_{\mathrm{s}}\right)$, and therefore turgor potential $\left(\Psi_{\mathrm{p}}\right)$ was maintained throughout the sampling period. Regardless of fruit turgor maintenance, the weight of D1 fruit was reduced from 135 DAFB. Weight, sugar concentration, and water relations of D2 fruit were not affected by deficit irrigation. This indicates that fruit water relations and sugar concentration are modified if water deficit is imposed from early in the season. However, if water deficit is imposed later in the season it has less impact on the composition and water relations of the fruit.
\end{abstract}

Apple production, important in many countries, often relies on irrigation (Childers, 1983). Deficit irrigation is a technique of reducing water supply to the plant at strategic times to levels that cause the water potential of the plant to decline to a predetermined level below the maximum possible at that time (Chalmers, 1989). Deficit irrigation therefore minimizes water use and reduces environmental problems such as leaching of nutrients and pesticides through the soil to ground water. Vegetative growth is decreased under deficit irrigation (Chalmers, 1989), which reduces pruning costs. Additionally, fruit quality may be improved under deficit irrigation (Mills et al., 1994). For apples, the effect of deficit irrigation on both the leaf water relations (Wang and Stutte, 1992) and vegetative growth (Irving and Drost, 1987) have been studied. Less is known about fruit water relations, and specifically under water deficit conditions. In this paper, we explore the fruit water relations and composition of apples under differing conditions of deficit irrigation. Our objective was to obtain information on the water relations and composition of apple fruit under deficit irrigation, and to explore the possibility of osmotic adjustment by the fruit.

Different organs on the same plant are known to have different sensitivities to deficit irrigation, with fruit growth being generally less sensitive to water deficit than vegetative growth (Higgs and Jones, 1991). We hypothesized that fruit under deficit irrigation osmotically adjust, which results in the maintenance of fruit turgor potential $\left(\Psi_{\mathrm{p}}\right)$, allowing a continuation of growth. Osmotic adjustment, as referred to in this study, is defined as the decrease in osmotic potential $\left(\Psi_{s}\right)$ greater than that which can be explained by solute concentration due to dehydration (Kramer, 1983). To test this hypothesis, fruit water potential $\left(\Psi_{\mathrm{w}}\right)$ and its components were measured. Fruit soluble sugars and $\mathrm{K}^{+}$were also determined because of their importance in osmotic adjustment (Morgan, 1984).

Received for publication 8 May 1995. Accepted for publication 7 July 1995. Technical assistance from Colin Tod and Chris Rawlingson is gratefully acknowledged. The cost of publishing this paper was defrayed in part by the payment of page charges. Under postal regulations, this paper therefore must be hereby marked advertisement solely to indicate this fact.

\section{Materials and Methods}

Three-year-old 'Braeburn' apple trees, growing in 60-liter black polythene bags, on MM106 rootstock were placed in a naturally-lit glasshouse on 10 Nov. 1993 (24 days after full bloom (DAFB) which occurred on 17 Oct. 1993). The photoperiod ranged from about 15 to $13 \mathrm{~h}$ during the experiment. Regular pesticide sprays were applied to control mites, aphids, and powdery mildew. The glasshouse floor was soil, covered with black polythene. The $\mathrm{C}$ trees were placed directly onto the floor, but deficit-irrigated trees were placed on 20-cm tall metal crates to prevent them from taking up water drained from the $\mathrm{C}$ trees. Trees were about $2 \mathrm{~m}$ tall. Once final fruit set was determined (30 DAFB), fruit number per tree was reduced to 20 . Some trees required additional structural support, which was provided by attaching a piece of twine to support wires $3 \mathrm{~m}$ above the ground to the top of each tree. The mean glasshouse temperature during the experiment was $22.2 \mathrm{C}$. Potential evaporation, calculated from meteorological data using the Penman equation, averaged $2.5 \mathrm{~mm} / \mathrm{day}$. Soil temperature was measured in one bag of each treatment using a monolithic temperature probe (LM 35; National Semiconductor Cooperation, Santa Clara, Calif.). The root medium was a 1:1:1 mix of sand, fine bark (particle size $<0.5 \mathrm{~mm}$ ), and peat with a bag capacity of about 24 liters of water in 60 liters of media. Bag capacity refers to the water content maintained within the bag once drainage has ceased. The concentrations $\left(\mathrm{g} \cdot \mathrm{m}^{-3}\right)$ of nutrients added to the mix were: $110 \mathrm{Mg}$, $244 \mathrm{Ca}, 42.4 \mathrm{P}, 36.55 \mathrm{~S}, 110 \mathrm{~N}, 4.3 \mathrm{Fe}, 0.625 \mathrm{Mn}, 0.25 \mathrm{Zn}, 0.125$ $\mathrm{Cu}, 0.0125 \mathrm{Mo}$, and $46.4 \mathrm{~K}$. A total of 52 experimental trees were assigned to treatments in a completely randomized design with 21 , 18 , and 13 trees assigned to C, D1, and D2 treatments, respectively. The $\mathrm{C}$ treatment received daily irrigation to initiate drainage from the bag; D1 was irrigated every second day from 55 to 183 DAFB (final harvest); and D2 was irrigated as C until 105 DAFB when irrigation was reduced to the level for D1 until 183 DAFB. Fewer trees were assigned to D2 than to C and D1, as the experimental period for $\mathrm{D} 2$ was shorter and less samples were required. The $\mathrm{C}$ plants received 4 liters of water per plant per day. The D1 and D2 
plants received between 1.5 and 4 liters per plant every second day throughout their deficit irrigation period. Preliminary soil moisture determinations gave an estimate of daily water use of individual trees. The deficit irrigation treatment was done by attempting to provide about $50 \%$ of this estimated water use. Regular measurements of volumetric water content $(\theta)$ and $\Psi_{1}$ allowed modification of irrigation levels for deficit-irrigated trees. The total irrigation amount given to each treatment was about 512 liters/tree for C, between 96 and 256 liters/tree for D1, and between 258 and 356 liters/tree for D2. Each D1 tree was irrigated at least 256 liters less, and each D2 tree at least 156 liters less than a C tree.

Volumetric water content of the soil was measured every few days using time domain reflectometry (TDR) equipment (Tektronix 1502C cable tester, Redmond, Ore.) (Topp and Davis, 1985). A three-pronged, $40-\mathrm{cm}$ TDR probe was inserted into the root zone of each tree. The TDR probe was inserted from the top of the 45$\mathrm{cm}$ bag on such an angle as to penetrate the root mass of the tree. Leaf water potential was recorded three times a week, between 1200 and $1300 \mathrm{HR}$, on one leaf per tree, using a Scholander-type pressure bomb (Soil Moisture Equipment, Santa Barbara, Calif.). Leaf water potential was measured at 2.5- to 4-h intervals from predawn to dusk at 64, 92, 106, 120, 133, 148, and 162 DAFB. Diurnal measurements were made on five leaves per tree at each time throughout the day. Trees that were scheduled for fruit sampling the following day and then removed from the experiment were used for these diurnal $\Psi_{1}$ measurements.

Photosynthesis, transpiration, and stomatal conductance $\left(\mathrm{g}_{\mathrm{s}}\right)$ were recorded weekly on one leaf per tree, using a portable photosynthesis system (Li-6200; Li-Cor, Lincoln, Neb.). The youngest mature leaves were selected from current season's growth and were in full sunlight at the time of measurement. Data were collected between 1200 and 1400 HR. Photosynthetically active radiation (PAR) was measured with the Li-Cor 6200, and the leaf internal $\mathrm{CO}_{2}$ concentration was calculated using this instrument.

Leaf area, measured on 48 trees at fruit sampling, was estimated by removing every tenth leaf from each tree. The approximated $10 \%$ leaf area of each tree was measured using an area meter $(\mathrm{Li}-$ Cor 3100; Li-Cor), and total leaf area per tree was subsequently calculated. Trunk-circumference was measured $2 \mathrm{~cm}$ above the graft union on 18 trees at 27 DAFB, and at 183 DAFB. Shoot length was measured weekly from 59 DAFB on two shoots per tree until 109 DAFB, when shoot growth ceased.

Fruit samples were taken eight times at 2-week intervals. For the first seven sampling dates, two trees per treatment, previously assigned to specific sampling times, were strip picked and all fruit analyzed. At final harvest, there were seven trees for C and D2, and four trees for D1 sampled. Fruit sampling from different trees was considered necessary to avoid any influences that a declining crop load over the season might have had on the measured fruit parameters.

Individual fruit were weighed. Total soluble solids (TSS) were determined on individual fruit using an automatic compensation refractometer (Atago ATC-1, Tokyo). From the 20 fruit harvested per tree, four composite samples each consisting of five fruit were prepared and subsequently analyzed. Composite fruit samples were measured for titratable acidity (TA) using an automatic titrator (Mettler DL21, Greifensee, Switzerland), $\mathrm{K}^{+}$concentration using an atomic absorption spectrometer (904AA; GBC scientific equipment PTY, Dandenong, Victoria, Australia), and sugar content using high performance liquid chromatography (HPLC) with a HPX87C carbohydrate analysis column, and de-ashing guard column (Life Science Group, Hercules, Calif.). Sample preparation for sugar and $\mathrm{K}^{+}$determinations followed Mills et al. (1994). Fruit water relations were determined on seven dates throughout the season on two fruit per treatment sampled between 0700 and $0800 \mathrm{HR}$. Fruit water potential was determined using a dew point hygrometer with a HR-33T microvoltmeter and employing C-52 sample chambers (Wescor Inc., Logan, Utah). Disks of fruit were taken from the outer equatorial portion of the fruit, excluding the skin, and placed into C-52 sample chambers and left to equilibrate
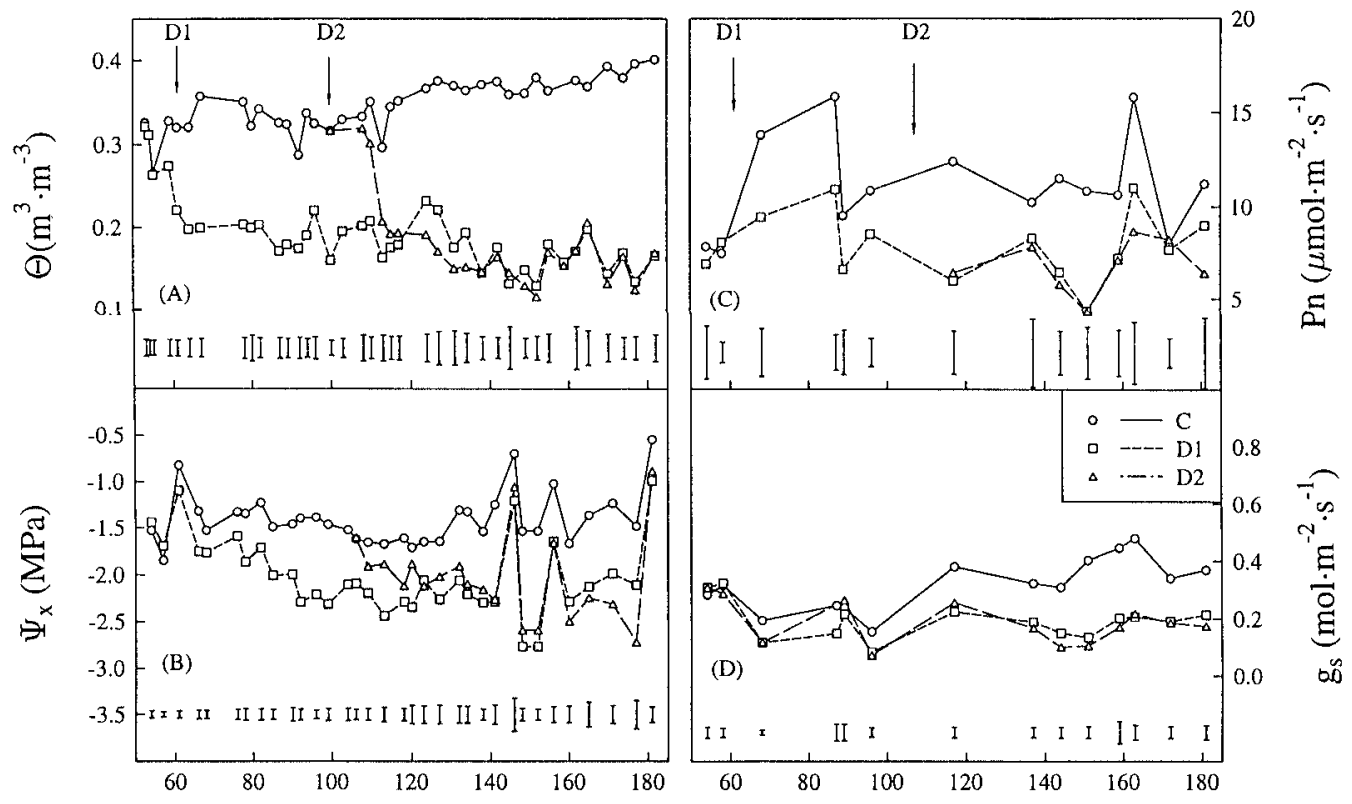

Days after full bloom

Fig. 1. Changes in soil volumetric water content $(\theta)(\mathbf{A})$, leaf water potential $\left(\Psi_{1}\right)(\mathbf{B})$, net photosynthesis $(\mathrm{Pn})(\mathbf{C})$, and stomatal conductance rate $\left(\mathrm{g}_{\mathrm{s}}\right)(\mathbf{D})$ during the season for C, D1 and D2 treatments. C (control, fully watered throughout the experimental period), D1 (deficit irrigation from 55 days after full bloom (DAFB) until final harvest), and D2 (deficit irrigation from 105 DAFB until final harvest). The start of D1 and D2 treatments is shown by arrows. Separate bars are pooled standard error of the means for at least 18 trees. 
Table 1. Effects of water stress on vegetative growth of 'Braeburn' apple trees.

\begin{tabular}{lccc}
\hline \hline Treatment & $\begin{array}{c}\text { Total leaf area } \\
\left(\mathrm{m}^{2}\right)^{\mathrm{z}}\end{array}$ & $\begin{array}{c}\text { Trunk circumference } \\
\text { increase }(\mathrm{mm})\end{array}$ & $\begin{array}{c}\text { First-year-wood } \\
\text { length }(\mathrm{m})\end{array}$ \\
\hline $\mathrm{C}$ & $1.84 \pm 0.84 \mathrm{~A}^{\mathrm{y}}$ & $13.5 \pm 1.31 \mathrm{~A}$ & $10.6 \pm 1.29 \mathrm{a}$ \\
$\mathrm{D}^{\mathrm{x}}$ & $1.37 \pm 0.92 \mathrm{~B}$ & $4.07 \pm 1.61 \mathrm{~B}$ & $6.21 \pm 1.62 \mathrm{~b}$ \\
$\mathrm{D}^{\mathrm{w}}$ & $1.76 \pm 1.04 \mathrm{~A}$ & $9.87 \pm 1.29 \mathrm{~A}$ & $7.52 \pm 1.27 \mathrm{ab}$
\end{tabular}

${ }^{\mathrm{z}}$ Mean values of 48 trees (19 for C, 16 for D1, and 13 for D2)

${ }^{\mathrm{y}}$ Means in columns followed by the same letter are not significantly different

yUppercase letters indicate significant difference at $P<0.05$, lowercase letters indicate significant difference at $P<0.10$.

${ }^{\mathrm{x}}$ Deficit irrigated from 55 to 183 DAFB (Final harvest).

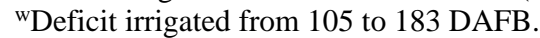

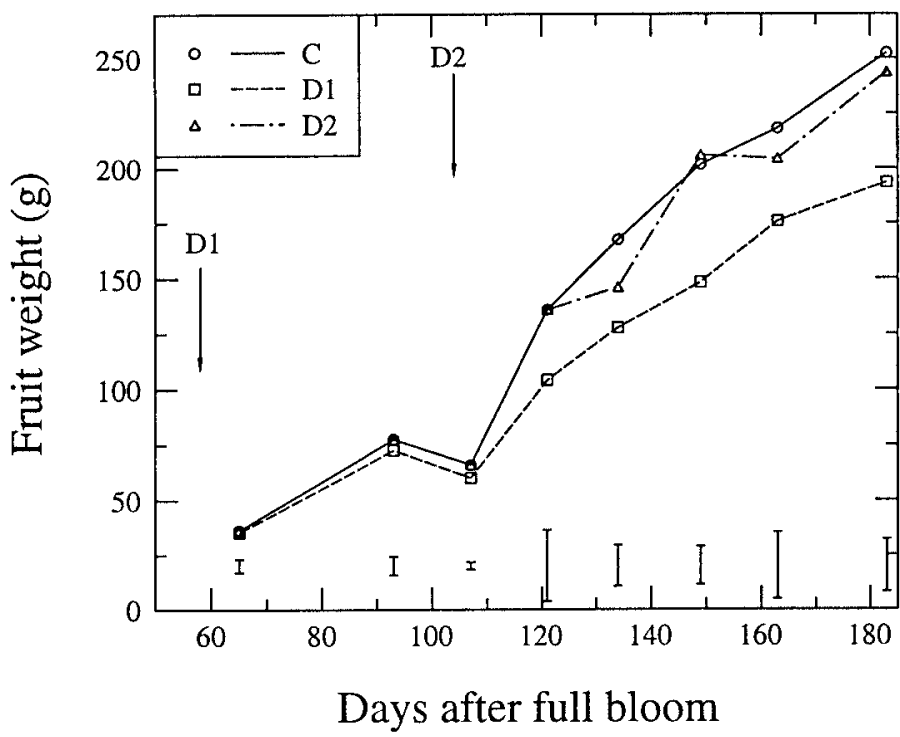

Fig. 2. Mean fruit weight during the season for C, D1, and D2 trees. Separate bars are pooled standard errors of the mean for 4 trees at 65, 93, 107, and 121 DAFB; 6 trees for 135, 149, and 163 DAFB; and 18 trees at 183 DAFB.

for at least $1 \mathrm{~h}$. Once $\Psi_{\mathrm{w}}$ had been determined the disks were wrapped in clear plastic and aluminum foil, and dipped into liquid air. After thawing, osmotic potential $\left(\Psi_{\mathrm{s}}\right)$ was determined with the hygrometer. Turgor potential $\left(\Psi_{\mathrm{p}}\right)$ was calculated as the difference between $\Psi_{\mathrm{w}}$ and $\Psi_{\mathrm{s}}$.

Treatment differences were determined by analysis of variance (ANOVA) using the GLM procedure of SAS (SAS Inst., Cary, N.C.). All data were analyzed by sample date and pooled standard errors presented. Leaf area was assessed periodically throughout the season on trees as they were harvested. Therefore, time of leaf area measurement was used as a covariate in the leaf area analysis. Total length of first-year wood, and trunk circumference increase were analyzed using initial trunk circumference as a covariate.

\section{Results}

Values of $\theta$ and $\Psi_{1}$ were lower in D1 and D2 treatments than in C during the deficit irrigation period (Fig. $1 \mathrm{~A}$ and B). Differences in $\theta$ developed over about 10 days. In $C$ bags $\theta$ ranged from 0.30 to 0.40 $\mathrm{m}^{3} \cdot \mathrm{m}^{-3}$, which was always at or near bag capacity. In the D1 and D2 bags during the deficit period, $\theta$ was reduced to between 0.15 and 0.20 $\mathrm{m}^{3} \cdot \mathrm{m}^{-3}$. For control trees, $\Psi_{1}$ ranged between -1.0 and $-1.75 \mathrm{MPa}$. The $\Psi_{1}$ was lower in D1 than in C trees from $61 \mathrm{DAFB}$, and lower in D2 than in C trees from 109 DAFB. Diurnal measurements showed reduced $\Psi_{1}$ in D1 and D2 trees compared to $\mathrm{C}$ throughout the day at

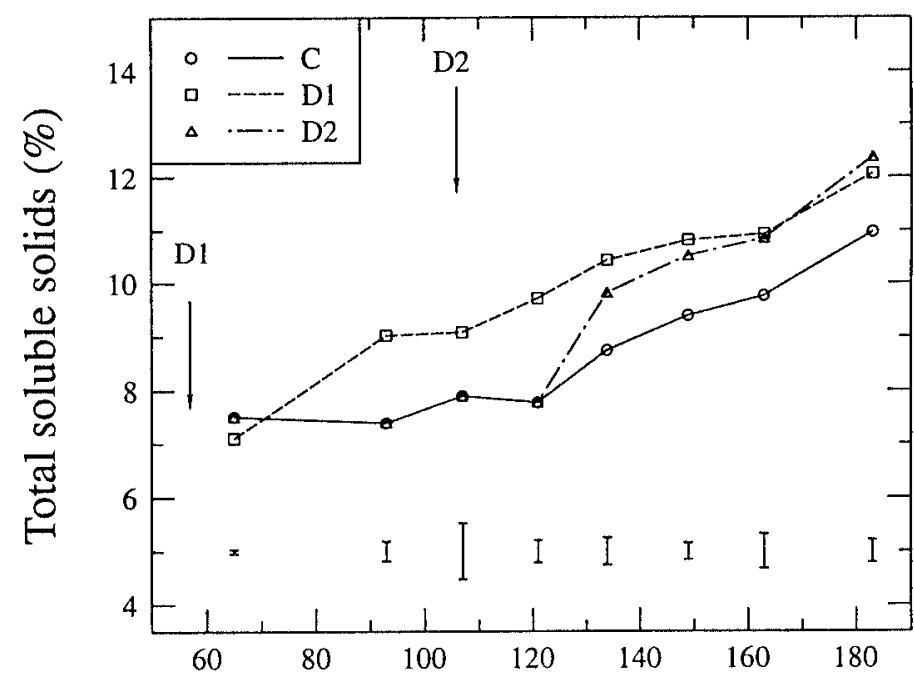

Fig. 3. Mean soluble solids during the season for C, D1, and D2 fruit. Separate bars are pooled standard errors for 4 trees at $65,93,107$, and 121 DAFB; 6 trees for 135,149 , and $163 \mathrm{DAFB}$; and 18 trees at $183 \mathrm{DAFB}$.

$92,106,120,133,148$, and 162 DAFB. For example, measurements taken at 133 DAFB showed a minimum difference among the treatments at $0500 \mathrm{HR}$ and a maximum difference at $1930 \mathrm{HR}$. At 0500 $\mathrm{HR}$, the $\Psi_{1}$ values (MPa $\pm \mathrm{SE}$ ) were $-0.29 \pm 0.04,-0.31 \pm 0.04$, and $0.48 \pm 0.04$ for $\mathrm{C}, \mathrm{D} 1$, and $\mathrm{D} 2$, respectively. The corresponding values at $1930 \mathrm{HR}$ were $-0.77 \pm 0.09,-1.44 \pm 0.09$, and $-1.64 \pm 0.09$. It was at 64 DAFB (only 9 days after deficit irrigation started) that differences between the treatments were not marked (data not shown).

No difference in soil temperature existed between treatments, with the mean being 21.4C. Lower photosynthetic rates of D1 trees, compared to C, were recorded from 68 to 163 DAFB (Fig. 1C). The photosynthetic rate was similarly reduced in the D2 trees from 117 DAFB to harvest. Some difference in $\mathrm{g}_{\mathrm{s}}$ was observed between treatments early in the season, but a larger difference was apparent later in the season (Fig. 1D). No significant difference in mean internal $\mathrm{CO}_{2}$ concentration in D1 and D2 leaves, when compared to $\mathrm{C}$, were observed over the entire experimental period. Mean values $\left(\mu \mathrm{mol} \cdot \mathrm{mol}^{-1} \pm \mathrm{SE}\right)$ were $293 \pm 2.9,294 \pm 3.2$, and $299 \pm 4.2$ for C, D1, and D2, respectively. Photosynthetic rate was not different among treatments at 172 and $181 \mathrm{DAFB}$ despite reduction in $\mathrm{g}_{\mathrm{s}}$ of D1 and D2, compared to $\mathrm{C}$ on these occasions. The PAR within the glasshouse tended to be lower on these days compared to other days of measurement. However, the PAR levels during measurements were always above the saturation level of $400 \mu \mathrm{mol} \cdot \mathrm{s}^{-1} \cdot \mathrm{m}^{-2}$, which was reported for apples (Campbell et al., 1992). We cannot offer any explanation for the reduction in photosynthetic rate of $\mathrm{C}$ trees on these dates. Transpiration rates, measured on individual leaves of D1 and D2 trees, were found to be lower than those of $\mathrm{C}$ from 137 DAFB (data not shown). Vegetative growth measured as trunk circumference increase, total leaf area, and total length of first-year growth were less in D1 trees than in C (Table 1). Control and D2 trees differed in trunk circumference only (Table 1).

Fruit weight was less in D1 than in C from 135 DAFB (Fig. 2). No reduction in fruit weight was recorded for D2. Fruit TSS for D1 and D2 were higher than $\mathrm{C}(P<0.05)$ from 93 and 134 DAFB, respectively (Fig. 3). Concentration of fructose, sorbitol, and total soluble sugars tended to be higher in D1 fruit than in C and D2 (Fig. 4). These differences were significant $(P<0.05)$ for $93,121,134$, and 183 DAFB. Titratable acidity was higher $(P<0.05)$ in D1 than $\mathrm{D} 2$ and $\mathrm{C}$ fruit at $183 \mathrm{DAFB}$. The mean values (as percent malic 


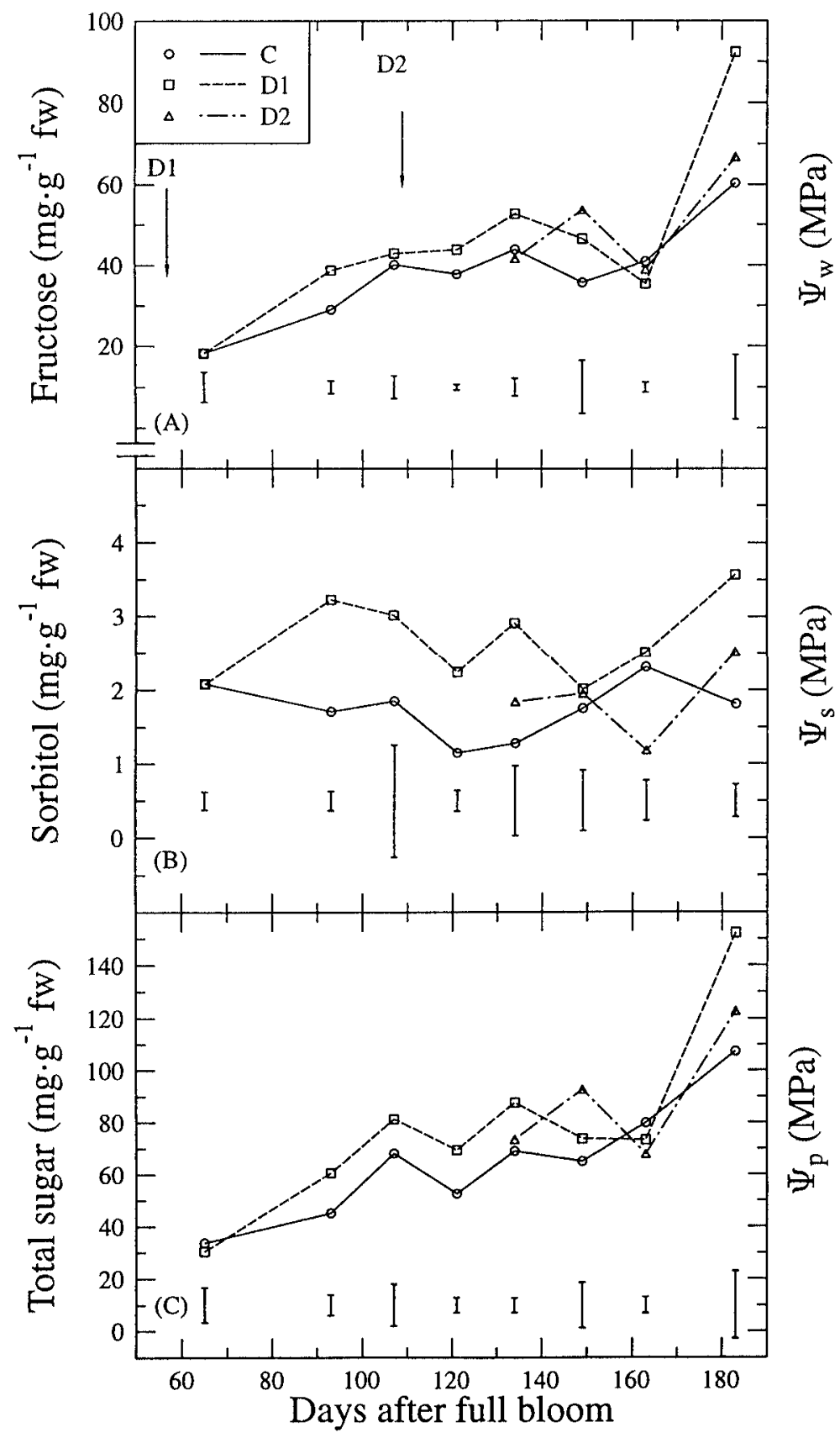

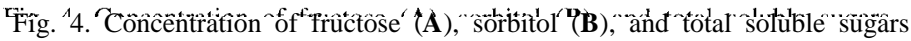
(fructose, glucose, sucrose, and sorbitol) (C) during the season for C, D1, and D2 fruit. Separate bars are pooled standard errors for 4 trees at 65, 93, 107 and 121 DAFB; 6 trees at 135, 149, and 163 DAFB; and 18 trees at 183 DAFB.

$\operatorname{acid} \pm \mathrm{SE}$ ) were $0.74 \pm 0.02,0.62 \pm 0.02$, and $0.60 \pm 0.02$ for D1, D2, and $\mathrm{C}$, respectively. The concentration of $\mathrm{K}^{+}$was also higher $(P<$ $0.05)$ in D1 fruit than in D2 and C at 183 DAFB, with the mean values $\left(\mathrm{mg} \cdot \mathrm{g}^{-1}\right.$ dry weight $\pm \mathrm{sE}$ ) being $10.2 \pm 0.52,8.86 \pm 0.40$, and $8.88 \pm 0.40$ for D1, D2, and C, respectively. Fruit $\Psi_{\mathrm{w}}$ and $\Psi_{\mathrm{s}}$ tended to be lower in D1 than C (Fig. $5 \mathrm{~A}$ and B). However, fruit $\Psi_{\text {p was }}$ similar among treatments (Fig. 5C). A linear decline $(P<0.05)$ in both $\Psi_{\mathrm{w}}$ and $\Psi_{\mathrm{s}}$ was observed for C and D1 fruit as the season progressed. The $\Psi_{\mathrm{p}}$ based on these data remained constant.

\section{Discussion}

Reduced $\Psi_{1}$ paralleled the reduction in photosynthetic rate in

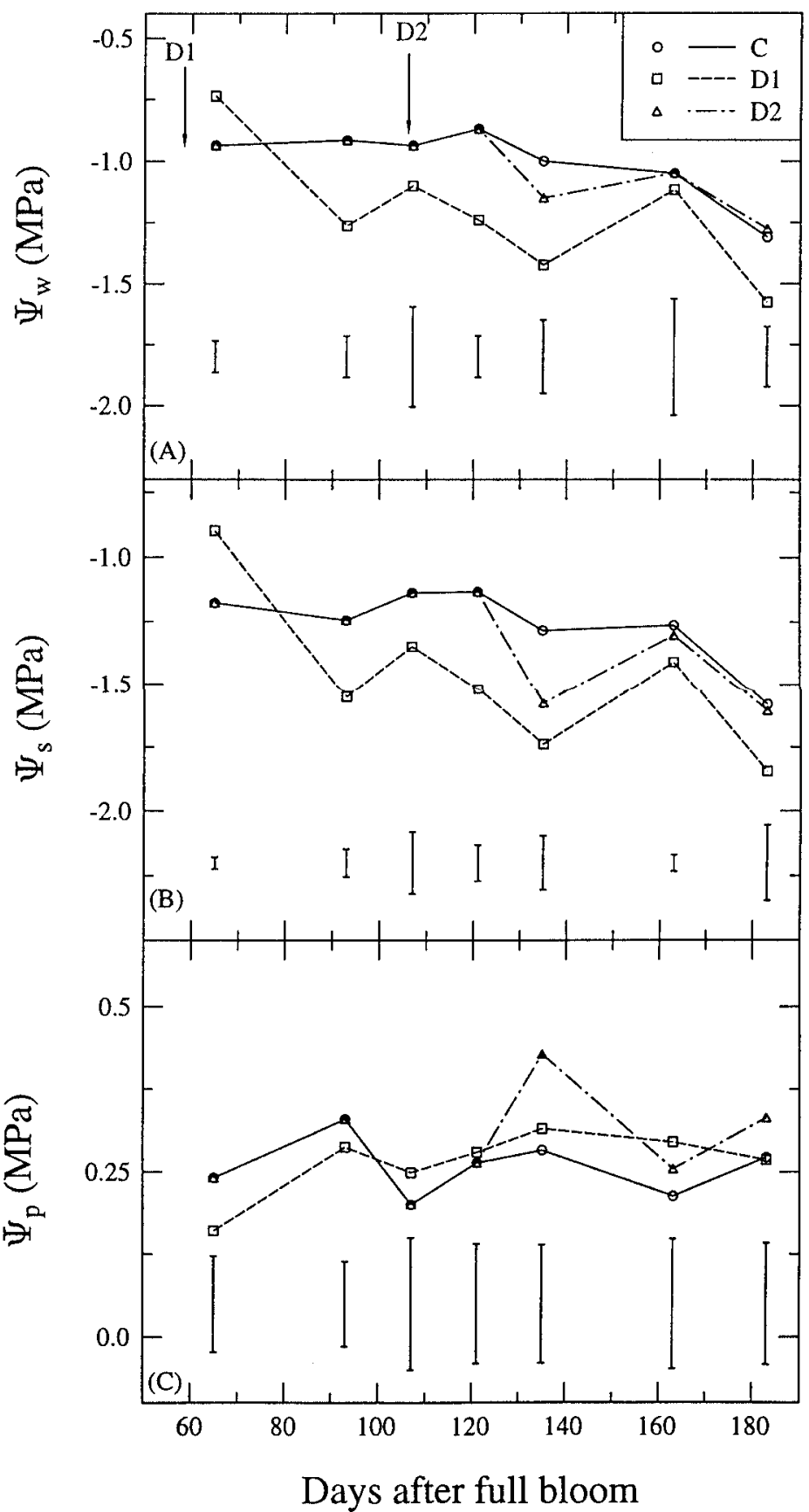

Fig. 5. Water potential $\left(\Psi_{\mathrm{w}}\right)(\mathbf{A})$, osmotic potential $\left(\Psi_{\mathrm{s}}\right)(\mathbf{B})$, and turgor potential $\left(\Psi_{\mathrm{p}}\right)$ (C) during the season for C, D1, and D2 fruit. Separate bars are pooled standard errors for 4 trees at $65,93,107$, and 121 DAFB; 6 trees at $135 \mathrm{DAFB} ; 5$ trees at 163 DAFB; and 17 trees at 183 DAFB.

$\mathrm{D} 1$ and $\mathrm{D} 2$ trees during the stress period when compared to $\mathrm{C}$ (Fig. 1). In apple trees, $g$ has been found to be closely correlated to photosynthetic rate over a wide range of water stresses, stomatal control being dominant under stress and non-stress conditions (Lakso and Seeley, 1978). The lack of difference in leaf internal $\mathrm{CO}_{2}$ concentration among our treatments indicates that non-stomatal mechanisms could have been responsible for the reduction of photosynthesis as reviewed by Hsiao (1993).

Lakso et al. (1984) observed that total leaf area decreases under water stress in apples and is one of the most sensitive parameters to reduced plant water status. Furthermore, Iancu (1985) showed that apple trunk growth rate was more sensitive to reduced irrigation than fruit growth. The reductions in both trunk circumference 
growth and total leaf area in D1 trees support these previous findings. A reduction in trunk circumference growth was also observed for D2 trees when compared to $\mathrm{C}(P<0.10)$. This indicated that, even late in the season, trunk growth is still occurring and may be sensitive to deficit irrigation. There was no significant reduction in leaf area of D2 trees, which may be due to the stress developing late in the season when shoot growth and leaf development were near completion (Palmer, 1988).

Fruit growth is reported to be less sensitive to water stress than other above-ground portions of the tree (Chalmers, 1989; Forshey and Elfving, 1989; Iancu, 1985). This may be because photosynthesis is less sensitive to water stress than vegetative growth, and reduced vegetative growth under water stress may allow increased availability of photoassimilates to the fruit. Fruit cells are strong solute sinks that attract water efficiently and are therefore less affected by water deficit than vegetative portions of the tree (Chalmers, 1989). Chapman's (1971) observation that water potential was generally higher in apple fruit than in the leaves is confirmed by our data. Behboudian et al. (1994) found that in Asian pear (Pyrus serotina Rehd.) values at midday of fruit water potential were higher than leaf water potential. Since fruit transpiration is usually negligible, most of water loss from fruit occurs as it is drawn out of fruit into xylem (Klepper, 1968). The higher water potential in the fruit, compared to the leaf, could be partially due to a high resistance to water movement out of fruit to leaves, which are the main sites of transpiration.

For D1 fruit there was a trend for reduced $\Psi_{w}$ compared to C (Fig. 5A). However, $\Psi_{\mathrm{s}}$ was also similarly reduced (Fig. 5B) resulting in the maintenance of $\Psi_{\mathrm{p}}$ (Fig. 5C). This suggests a possibility of osmotic adjustment in apple fruit under such a stress situation. However, maintenance of turgor may not necessarily result in maintenance of fruit growth. It is possible that cell wall elasticity allowed turgor maintenance in fruit cells with a reduction in cell size (Dainty, 1976) resulting in smaller fruit as was observed for D1 from 135 DAFB. The scope of our data does not allow a substantiation of this.

Active osmotic adjustment relies on the accumulation of solutes within the cells of the organ under water stress. Solutes that play an important role in the reduction of $\Psi_{\mathrm{s}}$ include soluble sugars, amino acids, organic acids, and mineral ions such as $\mathrm{K}^{+}$(Morgan, 1984). Failla et al. (1992) speculated that fruit compositional changes under reduced plant water status may result in fruit osmotic adjustment. Berüter (1989) showed osmotic adjustment in apple fruit, if carbon-assimilate supply was increased to fruit. The increase in fructose, sorbitol, and total soluble sugar concentration in the D1 fruit at 93, 121, and 134 DAFB (Fig. 4) corresponded to a reduction of $\Psi_{\mathrm{s}}$ on these dates (Fig. 5C). The observed accumulation of sugars may be a concentration effect due to reduced cell water content in the D1 fruit. However fruit weight was not significantly reduced until 135 DAFB, indicating that increased sugar levels were not solely due to reduced tissue volume. When using hygrometer equipment, sample solute concentration may be diluted due to the presence of apoplastic water. This inherent problem with the procedure means that $\Psi_{\mathrm{s}}$ values might have been more negative and therefore $\Psi_{\mathrm{p}}$ values higher than those of Fig. 5. The tendency for osmotic adjustment would then be stronger than our data suggest.

Although reduced plant water status, severe enough to reduce photosynthesis, occurred in the D2 trees, no reduction in fruit weight or growth occurred compared to those of $\mathrm{C}$. This is in agreement with data on Asian pears (Behboudian et al., 1994) and apple (Irving and Drost, 1987), which showed no reduction in fruit size when stress was imposed late in the season. There was no difference in fruit water relations between $\mathrm{C}$ and $\mathrm{D} 2$ fruit. Total soluble solids, however, were higher in D1 and D2 than in C. Since the total sugar concentration was only slightly higher in D2 fruit than in C fruit (Fig. 4C), other components of TSS in D2 fruit should have increased under deficit irrigation. The scope of our data does not allow specification of these components.

Water deficit early in the season may cause modifications in fruit composition and water relations, but water deficit late in the season has a minimal influence. The latter may be due to the relative strength of the near-mature fruit as a sink for water and carbohydrates. Because $\Psi_{\mathrm{s}}$ of all fruit generally gets lower through the season as fruit ripen (Berüter, 1989), fruit become more effective competitors for available water. Thus, fruit water relations are often unaffected despite a reduction in $\Psi_{1}$ of the tree. A reduction in trunk circumference growth in the D2 trees late in the season may have been due to reduced carbon assimilation as indicated by a decreased photosynthetic rate and/or competition for photoassimilates with fruit sinks.

This study showed that apple fruit are strong sinks for water within the plant. As they mature they are able to maintain their water potential under deficit irrigation while leaves show a reduction in this parameter. Early in the season, however, fruit water relations are influenced by deficit irrigation and fruit undergo some osmotic adjustment, which helps maintain turgor and growth. Fruit water relations affect fruit composition and therefore some of the fruit quality attributes. This research was carried out in a glasshouse to facilitate consistent data collection. Field studies at this lab have shown an improvement in some fruit quality attributes under reduced plant water status with a minimal reduction in fruit size (Mills et al., 1994). In addition to improvement of fruit quality, this study showed that deficit irrigation can also contribute to substantial savings in the amount of irrigation water used. Because apple fruit growth appears resilient to plant water stress, deficit irrigation may become an effective management strategy.

\section{Literature Cited}

Behboudian, M.H., G.S. Lawes, and K.M. Griffiths. 1994. The influence of water deficit on water relations, photosynthesis and fruit growth in Asian pear (Pyrus serotina Rehd.). Scientia Hort. 60:89-99.

Berüter, J. 1989. Carbohydrate partitioning and changes in water relations of growing apple fruit. J. Plant Physiol. 135:583-587.

Campbell, R.J., R.P. Marini, and J.B. Birch. 1992. Canopy position affects light response curves for gas exchange characteristics of apple spur leaves. J. Amer. Soc. Hort. Sci. 117:467-472.

Chapman, K.R. 1971. Plant water status of apple trees and its measurement in the field. 6. Diurnal variations in the water potential of apple leaves and fruits of three varieties at two stress levels. Queensland J. Agr. Annu. Sci. 27:119-203.

Chalmers, D.J. 1989. A physiological examination of regulated deficit irrigation. N.Z. J. Agr. Sci. 23:44-48.

Childers, N.F. 1983. Modern fruit production : orchard and small fruit. $9^{\text {th }}$ ed. Hort. Publ., Gainesville, Fla.

Dainty, J. 1976. Water relations of plant cells, p. 12-35. In: U. Lüttge and M.G. Pitman (eds.). Transport in plants II. part A. Cells. SpringerVerlag, Berlin.

Failla, O., G. Zocchi, G. Treccani, and S. Cocucci. 1992. Growth, development and mineral content of apple fruit in different water status conditions. J. Hort. Sci. 67:265-271.

Forshey, C.G. and D.C. Elfving. 1989. The relationship between vegetative growth and fruiting in apple trees. Hort. Rev. 11:229-287.

Higgs, K. H. and H. G. Jones. 1991. Water relations and cropping of apple cultivars on a dwarfing rootstock in response to imposed drought. J. Hort. Sci. 66:367-379.

Hsiao, T.C. 1993. Growth and productivity of crops in relation to water status. Acta Hort. 335:137-148. 
Iancu, M. 1985. Growth rate of apple trunk and fruit-Additional indicators for water needs of fruit trees. Acta Hort. 171:417-425.

Irving, D.E. and J.H. Drost. 1987. Effects of water deficit on vegetative growth, fruit growth and fruit quality in Cox's Orange Pippin apple. J. Hort. Sci. 62:427-432.

Klepper, B. 1968. Diurnal pattern of water potential in woody plants. Plant Physiol. 43: 1931-1934.

Kramer, P. J. 1983. Water relations of plants. Academic Press, New York. Lakso, A.N. and E.J. Seeley. 1978. Environmentally induced responses of apple tree photosynthesis. HortScience 13:646-650.

Lakso, A.N., A.S. Geyer, and S.G. Carpenter. 1984. Seasonal osmotic relations in apple leaves of different ages. J. Amer. Soc. Hort. Sci. 109:544-547.
Mills, T.M., M.H. Behboudian, P.Y. Tan, and B.E. Clothier. 1994. Plant water status and fruit quality in 'Braeburn' apples. HortScience 29:12741278.

Morgan, J.M. 1984. Osmoregulation and water stress in higher plants. Annu. Rev. Plant Physiol. 35:299-319.

Palmer, J. W. 1988. Annual dry matter production and partitioning over the first 5 years of a bed system of Crispin/m.27 apple trees at four spacings. J. Applied Ecol. 25:569-578.

Topp, G.C. and G.L. Davies. 1985. Time-domain reflectometry (TDR) and it's application to irrigation scheduling. Adv. Irr. 3:107-127.

Wang, Z. and G. Stutte. 1992. The role of carbohydrates in active osmotic adjustment in apple under water stress. J. Amer. Soc. Hort. Sci. 117:816823. 